\title{
The Fecal M2-PK As A Novel Biomarker for Screening of Cancer Colon
}

\author{
Mohamed El-Tantawy Ibrahim ${ }^{1}$, Mohamed A. Mohamed ${ }^{1}$, Mona A. Elawady ${ }^{2}$ and Hala A. \\ Abed $^{2}$. \\ ${ }^{1}$ Internal Medicine Department, Faculty of Medicine, Benha University, Benha, Egypt. \\ ${ }^{2}$ Public Health and Community Medicine Department, Faculty of Medicine, Benha \\ University, Benha, Egypt.
}

Received: October, 2017 Accepted: December, 2017

\begin{abstract}
Background: Cancer colon is one of most common cancers worldwide. Colonoscopy; an invasive and costly investigation method is the most reliable tool for diagnosis. Early diagnosis of cancer colon gives a high chance of cure. Fecal M2-PK; a tumor biomarker is a new approach for cancer colon screening. Objective: This study aimed to evaluate fecal M2-PK as a biomarker for cancer colon screening. Methods: This comparative crosssectional study included 3 groups: 30 healthy individuals (Group I), 50 diagnosed cancer colon patients (Group $\Pi$ ) and 20 cancer colon patients who were the only operable patient from Group $\Pi$ (Group III). For all groups, history and physical examination was done. Fecal M2-PK concentrations were detected by ELISA. Results: The study revealed that there was a significant difference between cancer colon patients and healthy individuals (control) regarding age $\left(\mathrm{p}=0.046^{*}\right), \mathrm{BMI}(\mathrm{p}=0.004 *)$, history of smoking $\left(\mathrm{p}=0.025^{*}\right)$, history of low fiber and high protein diet $(\mathrm{p}=0.001 *)$, and levels of M2-PK $(\mathrm{p}=0.001 *)$. There was a significant difference in the mean value of M2PK levels in relation to sex $(\mathrm{p}=0.043 *)$ and site of cancer colon $(\mathrm{p}=0.002 *)$ only. Cancer colon can be detected with fecal M2-PK with remarkable sensitivity \&specificity ( $98 \%$ and $93 \%$ respectively). The overall accuracy of M2PK in detecting cancer colon was 96.6\%. Conclusion: Fecal M2$\mathrm{PK}$ is considered as a good screening biomarker for cancer colon.
\end{abstract}

Keywords: Cancer colon; M2-PK; Biomarker

Corresponding author: Mona Ahmed Elawady Email : dr_monaelawady@yahoo.com

\section{Introduction}

Cancer colon represents an important major health problem in the world, especially in developed countries. ${ }^{1}$ All over the world cancer colon consider the third common cancer, affecting about 1.23 million Patients annual. ${ }^{2}$

The incidence rate of cancer colon increased rapidly because it was associated with many risk factors related to life style such as smoking, sedentary lifestyle, obesity, diet that contain high red and processed meats, and alcohol abuse. ${ }^{3}$ In Egypt, The incidence rate ranges between 2-6\% of all cancer cases reported yearly and represents as the sixth common cancer in both male and female gender. ${ }^{4}$

Cancer colon is considered as a "silent" disease, a lot of patients do not develop alarm signs, like as bleeding or abdominal pain until the cancer became incurable. $^{5}$

The increasing incidence and related mortality, and the expected history of cancer colon with slow sequence from a precancerous polyp to cancer, make cancer colon very appropriate for people screening. ${ }^{6}$ Additional studies revealed 
that screening program and early prevention of cancer colon reduced the cost of management. ${ }^{7}$

The role of screening programs is detecting and removal of colonic precancerous lesions before they turn into cancerous or symptomatic. ${ }^{8}$

There are many screening tests for cancer colon which is divided into non-invasive stool or blood tests and invasive imaging or endoscopy procedures. 9 The goldstandard screening test is colonoscopy, with a sensitivity and specificity for discovering polyps and cancers more than $98 \% .^{10}$

New biomarkers that are simple, noninvasive, cost-efficient and practically sensitive/specific are immediately required. ${ }^{11}$ One of these biomarkers is tumor M2- pyruvate kinase; which is glycolytic isoenzyme pyruvate kinase type M2 (M2-PK). It has a main role in tumor cells and is expressed in human tumor tissues. The tissue-specific isoenzymes are replaced by M2-PK during the neoplastic process. In tumor cells there is a shift from the tetrameric form to a nearly inactive dimeric form. This predominantly raised M2-PK level also correlates with the presence of metastases. ${ }^{12}$

The aim of this work was to study stool M2-PK as a new biomarker for screening of cancer colon as this test is sensitive, specific, and not dependent on occult blood and no special precaution is needed before the test.

\section{Methods}

This comparative cross-sectional study was conducted in Benha university hospital and included eighty individuals. These were divided into three groups; group (I) thirty healthy individuals as a control, group (II) fifty cancer colon patients and group (III) twenty cancer colon patients (from patients of group II), six weeks post-surgical treatment; they were the only operable patients.

The studied individuals were selected from the outpatient clinics, Internal Medicine Department and surgical Department in Benha University hospital. The field work was carried out over the period between July 2016 and July 2017. For every patient, a written informed consent was obtained. An approval from the Research Ethics Committee in Benha Faculty of Medicine was obtained. Patient with cancer colon and other malignancies were excluded from the study.

For all subjects, complete history was obtained with concerning of age, gender, body mass index (BMI), smoking status, low fiber and high protein diet and family history of cancer colon, and physical examination was carried out.

The diagnosis of cancer colon was confirmed by pelvic- abdominal computed tomography, colonoscopy and histopathology.

For all groups stool samples were collected in Paper collecting devices and were stored for up to 48 hours at room temperature. No any precaution need before stool analysis as M2-PK test not affected by specific foods and no special diet required.

Fecal M2-PK concentrations were determined using a commercially sandwich ELISA's based on two monoclonal antibodies which specifically recognize Tumor M2-PK (the dimeric form of M2-PK).

According to the manufacturer instruction, a positive test result was defined as $>4$ U/ML.

\section{Statistical Analysis}

The collected data were summarized in terms of mean \pm SD for quantitative data and frequency and percentage for categorical data. Chi square test and Fisher exact test were used to compare 
Table 1: Age and sex distribution of control and cancer colon groups.

\begin{tabular}{|l|r|}
\hline & \multicolumn{1}{|c|}{ Value } \\
\hline Age (years) & $47.86 \pm 13.89$ \\
Mean \pm SD (range) & $(20-73)$ \\
\hline Sex: N (\%) & \\
- Male & $49(61.3)$ \\
- Female & $31(38.8)$ \\
\hline
\end{tabular}

The study was conducted on 80 participants, where 50 of them had Colon cancer and 30 were free of cancer. Their age ranged from 20 to 73 years old with mean value 47.86 \pm 13.89 . Regarding sex $61.3 \%$ were males (Table 1 ).

Table 2: Comparison between Cancer colon and control groups.

\begin{tabular}{|c|c|c|c|c|}
\hline 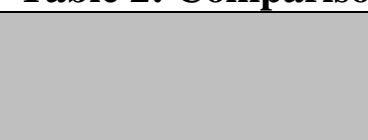 & $\begin{array}{l}\text { Cancer colon } \\
\text { group }(\mathbf{5 0}) \\
\text { Mean } \pm \text { SD }\end{array}$ & $\begin{array}{c}\text { Control group (30) } \\
\text { Mean } \pm \text { SD }\end{array}$ & $\begin{array}{l}\text { Statistical } \\
\text { test }\end{array}$ & $P$ value \\
\hline Age (years) & $50.26 \pm 13.46$ & $43.87 \pm 13.89$ & $\# 2.03$ & $0.046^{*}$ \\
\hline $\begin{array}{l}\text { Age groups } \\
<50 \\
50-54 \\
55-59 \\
60-64 \\
65-69 \\
\geq 70 \\
\end{array}$ & $\begin{array}{r}24(48.0) \\
5(10.0) \\
8(16.0) \\
2(4.0) \\
9(18.0) \\
2(4.0) \\
\end{array}$ & $\begin{array}{r}21(70.0) \\
3(10.0) \\
0(0.0) \\
2(6.7) \\
3(10.0) \\
1(3.3) \\
\end{array}$ & $\wedge 8.05$ & 0.13 \\
\hline $\begin{array}{l}\text { Sex } \\
\text { Male } \\
\text { Female }\end{array}$ & $\begin{array}{r}31(62.0) \\
19(38.0) \\
\end{array}$ & $\begin{array}{r}18(60.0) \\
12(40.0) \\
\end{array}$ & $\$ 0.03$ & 0.86 \\
\hline BMI & $28.18 \pm 3.25$ & $24.9 \pm 3.14$ & $\# 4.42$ & $0.001 * *$ \\
\hline $\begin{array}{l}\text { BMI groups } \\
\leq 25 \\
>25-30 \\
>30\end{array}$ & $\begin{array}{r}9(18.0) \\
31(62.0) \\
10(20.0)\end{array}$ & $\begin{array}{r}16(53.3) \\
12(40.0) \\
2(6.7) \\
\end{array}$ & $\wedge 10.87$ & $0.004 * *$ \\
\hline Smoking & $16(32.0)$ & $3(10.0)$ & $\$ 5.01$ & $0.025^{*}$ \\
\hline Positive family history & $3(6.0)$ & $1(3.3)$ & ${ }^{\wedge} 0.28$ & 1.0 \\
\hline $\begin{array}{l}\text { Low fiber high protein } \\
\text { diet }\end{array}$ & $38(76.0)$ & $0(0.0)$ & $\$ 43.43$ & $0.001^{* *}$ \\
\hline M2-PK (U/ML) & $9.36 \pm 2.72$ & $2.03 \pm 0.89$ & $\# 14.25$ & $0.001 * *$ \\
\hline
\end{tabular}

The results revealed that there was no significant difference between cancer colon patients and control groups regarding the age $(F E T=8.05, p$ value $=0.13)$ and $\operatorname{sex}\left(x^{2}=0.03, p\right.$ value $=0.86$ ). The study found a significant difference between cancer colon patients and control groups in regard to BMI $\left(\mathrm{x}^{2}=10.87, \mathrm{p}\right.$ value $\left.=0.004^{*}\right)$ as $62 \%$ of cases had BMI $>25-30$ in comparison to $40 \%$ of control group. $32 \%$ of Cancer colon group were smokers compared to $3.3 \%$ only of control group and this difference was statistically significant. Positive family history of Cancer colon group was revealed in $6 \%(3 / 50)$ of cases and $3.3 \%(1 / 30)$ of control .High percentage of cases $76 \%(38 / 50)$ consumed low fiber high protein diet, however no one in control group consumed such diet and this difference of statistically significant importance $(\mathrm{p}$ value $=0.001 *)$. Cancer colon group showed statistically significant ( $\mathrm{p}$ value $=0.001 *$ ) increased in M2-PK levels $9.36 \pm 2.72$ compared to levels of such marker in control group which was $2.03 \pm 0.89$ (Table 2). 
Table 3: Distribution of Cancer colon group regarding site of colon.

\begin{tabular}{|l|l|l|}
\hline $\begin{array}{l}\text { Cancer colon group (50) } \\
\text { Site of colon }\end{array}$ & No & \% \\
\hline Right & 16 & 32.0 \\
Left & 34 & 68.0 \\
Total & 50 & 100 \\
\hline
\end{tabular}

More than 60 percent of patients had cancer on the left side colon (Table 3). The distribution of M2-PK levels in regard to different factors, it was demonstrated that there was a significant difference in mean value of M2-PK levels in regard the sex (male $9.97 \pm 2.6$, female $8.37 \pm 2.69 \& \mathrm{p}$ value $\left.=0.043^{*}\right)$ and Right colon cancer show statistically significant $(\mathrm{P}$ value $=0.002 *)$ increase in $\mathrm{M} 2-\mathrm{PK}$ level $(11.06 \pm 2.69)$ more than Left side cancer (8.56 \pm 2.38$)$. The study revealed no significant difference in M2-PK levels regarding different age groups, BMI, smoking, family history or type of diet (Table 4).

Table 4: M2-PK levels regarding different groups in cancer colon patients.

\begin{tabular}{|c|c|c|c|}
\hline $\begin{array}{c}\text { Cancer colon group } \\
(\mathbf{5 0})\end{array}$ & $\begin{array}{c}\text { M2-PK } \\
\text { Mean } \pm \text { SD }\end{array}$ & $\begin{array}{c}\text { Student } t \\
\text { test }\end{array}$ & $P$ value \\
\hline $\begin{array}{l}\text { Sex } \\
\text { Male } \\
\text { Female }\end{array}$ & $\begin{array}{c}9.97 \pm 2.6 \\
8.37 \pm 2.69\end{array}$ & 2.08 & $0.043^{*}$ \\
\hline $\begin{array}{l}\text { Age groups } \\
<50 \\
50-54 \\
55-59 \\
60-64 \\
65-69 \\
\geq 70\end{array}$ & $\begin{array}{c}9.33 \pm 3.0 \\
7.4 \pm 1.34 \\
10.13 \pm 2.8 \\
9.5 \pm 2.12 \\
9.22 \pm 2.33 \\
12.0 \pm 2.83 \\
\end{array}$ & $\mathrm{~F}=1.03$ & 0.41 \\
\hline $\begin{array}{l}\text { BMI groups } \\
\leq 25 \\
>25-30 \\
>30\end{array}$ & $\begin{array}{l}9.11 \pm 2.32 \\
9.16 \pm 3.06 \\
10.2 \pm 1.87\end{array}$ & $\mathrm{~F}=0.59$ & 0.56 \\
\hline $\begin{array}{l}\text { Smoking } \\
\text { Yes } \\
\text { No }\end{array}$ & $\begin{array}{c}9.5 \pm 2.68 \\
9.29 \pm 2.78\end{array}$ & 0.25 & 0.81 \\
\hline $\begin{array}{l}\text { Family history } \\
\text { Yes } \\
\text { No }\end{array}$ & $\begin{array}{l}10.0 \pm 2.65 \\
9.32 \pm 2.75\end{array}$ & 0.42 & 0.68 \\
\hline $\begin{array}{l}\text { Low fiber high } \\
\text { protein } \\
\text { Yes } \\
\text { No }\end{array}$ & $\begin{array}{l}9.74 \pm 2.76 \\
8.17 \pm 2.33\end{array}$ & 1.78 & 0.08 \\
\hline $\begin{array}{l}\text { Site } \\
\text { Right } \\
\text { Left }\end{array}$ & $\begin{array}{c}11.06 \pm 2.69 \\
8.56 \pm 2.38\end{array}$ & 3.33 & $0.002 * *$ \\
\hline
\end{tabular}

There was no association between M2PK levels and age or BMI $(\mathrm{r}=0.07, \mathrm{P}$ value $=0.62 \&$ $\mathrm{r}=0.18, \mathrm{P}$ value $=0.12)$ respectively $($ Table 5$)$. The results showed a significantly $(\mathrm{P}$ value $=$ 
$0.001)$ marked decrease in mean value of M2PK between baseline level (10.15 \pm 2.03$)$ and its level 6 weeks later $(2.35 \pm 0.88)$ (Table 6).

Table 5: Correlation between M2-PK levels and age and BMI.

\begin{tabular}{|l|c|c|}
\hline \multicolumn{1}{|c|}{$\begin{array}{c}\text { Case group (50) } \\
\text { M2-PK }\end{array}$} & r test & P value \\
\hline Age & 0.07 & 0.62 \\
\hline BMI & 0.18 & 0.21 \\
\hline
\end{tabular}

Table 6: Differences between M2PK levels after 6 weeks follow up period (group w).

\begin{tabular}{|l|c|c|c|c|}
\hline \multicolumn{1}{|c|}{ Group II (20) } & $\begin{array}{c}\text { Baseline } \\
\text { Mean } \pm \text { SD }\end{array}$ & $\begin{array}{c}\text { 6 weeks later } \\
\text { post operative } \\
\text { Mean } \pm \text { SD }\end{array}$ & $\begin{array}{c}\text { Paired t } \\
\text { test }\end{array}$ & P value \\
\hline M2-PK (U/ML) & $10.15 \pm 2.03$ & $2.35 \pm 0.88$ & 18.83 & $0.001^{* *}$ \\
\hline
\end{tabular}

Table (7): Validity of M2-PK as a predictor of cancer colon:

\begin{tabular}{|c|c|c|c|c|}
\hline M2-PK & $\begin{array}{c}\text { Cancer colon } \\
\text { group }(50)\end{array}$ & $\begin{array}{c}\text { Control group } \\
\text { (30) }\end{array}$ & $X^{2}$ & $P$ value \\
\hline$\geq 3.5$ & $49(98.0)$ & $2(6.7)$ & \multirow[t]{2}{*}{67.68} & \multirow[t]{2}{*}{$0.001 * *$} \\
\hline$<3.5$ & $1(2.0)$ & $28(93.3)$ & & \\
\hline AUC & \multicolumn{4}{|c|}{0.996} \\
\hline Stand Error & \multicolumn{4}{|c|}{0.004} \\
\hline $95 \% \mathrm{CI}$ & \multicolumn{4}{|c|}{$0.99-1.0$} \\
\hline Cutoff point & \multicolumn{4}{|c|}{3.5} \\
\hline Sensitivity & \multicolumn{4}{|c|}{98.0} \\
\hline Specificity & \multicolumn{4}{|c|}{93.3} \\
\hline PPV & \multicolumn{4}{|c|}{96.1} \\
\hline NPV & \multicolumn{4}{|c|}{96.6} \\
\hline Accuracy & \multicolumn{4}{|c|}{96.3} \\
\hline
\end{tabular}

The study found that almost all cancer colon patients had M2PK level $\geq 3.5 \mathrm{U} / \mathrm{ML}$, however $93.3 \%$ of control had M2-PK level $<3.5 \mathrm{U} / \mathrm{ML}$ and this difference is statistically significant ( $\mathrm{p}$ value $=0.001 *)$. The AUC is $0.996(\mathrm{CI}=0.99-1)$, means that M2-PK is an excellent predictor for colon cancer. Colon cancer can be detected with remarkable sensitivity \&specificity ( $98 \%$ and $93 \%$ respectively). The overall accuracy of M2-PK in detecting colon cancer is $96.6 \%$ (Table 7 and Fig. 1).

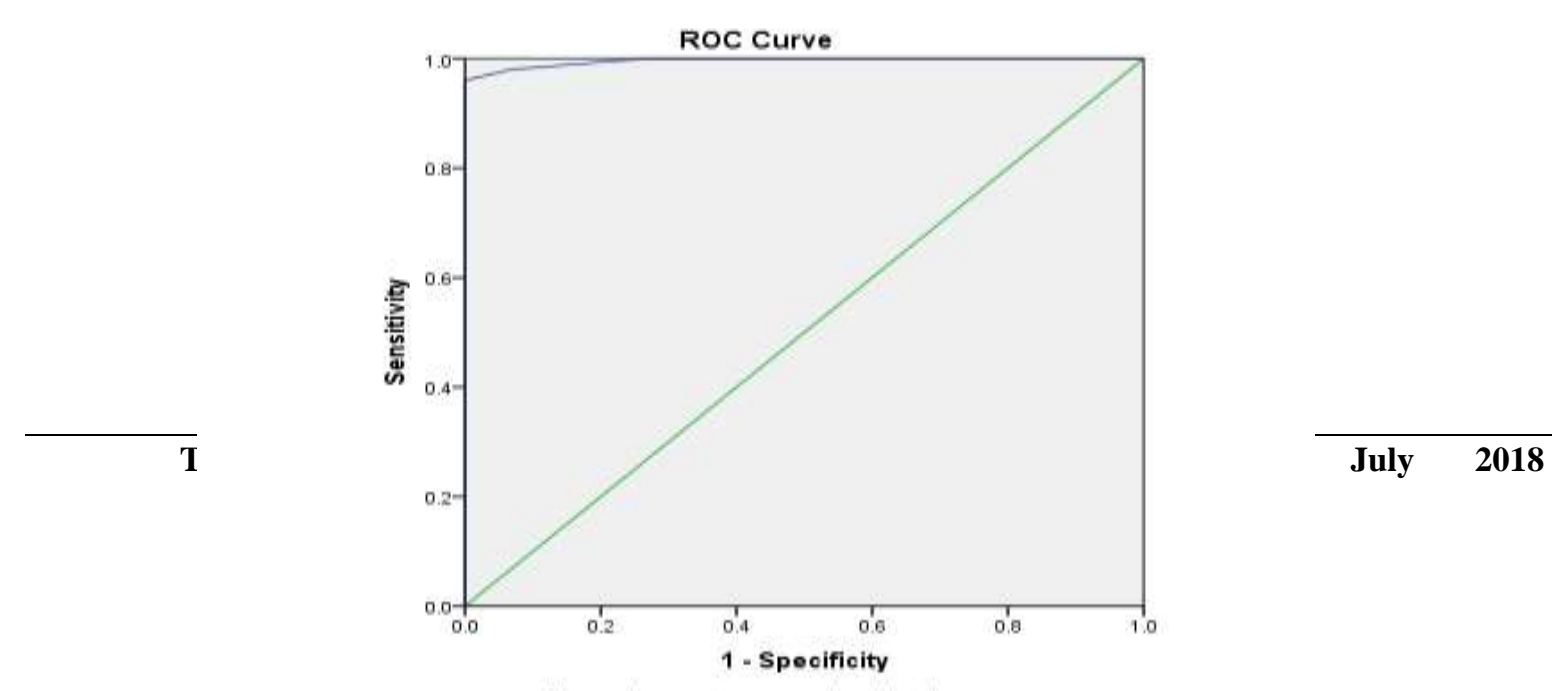




\section{Fig. 1: ROC curve showed the validity of M2-PK as a predictor of cancer colon.}

categorical variables while student $t$ test and ANOVA (F) test was used to compare quantitative variables. Paired $t$ test was used to compare M2-PK (U/ML) between base line and after follow up period of six weeks. The Pearson correlation coefficient (r) was used to assess the correlations between estimated parameters. The diagnostic performance of M2-PK for cancer colon patients was examined and the best cut off points and the corresponding sensitivity, specificity, Positive Predictive Value (PPV), Negative Predictive Value (NPV), accuracy and the Area Under the Curve (AUC) were estimated. A P-value $<0.05$ was considered statistically significant. All statistical analysis was carried out using the computerized Statistical Package for Social Science (SPSS; Version 20.0 for Windows, SPSS Inc., Chicago, IL).

\section{Discussion}

Cancer colon is a common malignancy all over the world. It affects men and women of all racial and ethnic groups and most of them were 50 years or older in developed countries. ${ }^{13}$ In this study, the age of the included population ranged between 20-73ys, with a mean of 50.26 \pm 13.46 years among cancer colon group patients; but more than fifty percent were older than 50years and it was $43.87 \pm 13.89$ years among control group. This comes in agreement with other studies in Egypt, as they found that the mean age of their assessed patients was 51 years but also $25 \%$ of cancer colon occurring among patients younger than 40 years. ${ }^{14,15}$

Males represented $62 \%$ in cancer colon patients group and $60 \%$ in control group in the present study, with no statistically significant difference $(\mathrm{p}>0.86)$. This was in agreement with other studies in
Thailand and United states; as they found that cancer colon affects men and women almost equally. ${ }^{16,17}$ In disagreement with this Murphy et al and Rim et al found that cancer colon is more common in men than women. ${ }^{18,19}$

In our study, there was no significant relation between tumor M2PK level and either age or sex. These results were in agreement with Hamilton et $\mathrm{al}^{20}$ who assessed 32 cancer colon patients with a median age 66 Ys (male to female ratio was 3:1) and found no association between fecal tumor M2PK level and patients' age or sex.

Nutritional related factors and body weight played a major role in cancer colon development. ${ }^{21}$ In this study we found a significant difference between the studied groups as regard BMI as $62 \%$ of cancer colon patients had BMI more than $30 \mathrm{~kg} / \mathrm{m}^{2}$ in comparison to $40 \%$ of control group. This was in agreement with many other studies concluded that, higher tumor M2PK levels were found in patients with higher BMI. $^{22,23,24}$ But Haug et $\mathrm{al}^{25}$ found no relationship between fecal M2PK levels and BMI so they addressed that obesity has no role in pathogenesis of cancer colon. The type of food consumed may affect the pathogenesis of cancer colon as high percentage of cancer colon patients $76 \%$ consumed low fiber and high protein diet and the mean level of M2PK in those patients was high $(9.36 \pm 2.72)$, however no one in control group consumed such diet and their mean level of M2PK was normal $(2.03 \pm 0.89)$ and this difference of food habit had a statistically significant importance ( $\mathrm{p} \quad$ value $=0.001)$. This supported other results obtained by other studies as they found a relation between cancer colon and high protein diet. ${ }^{26,27}$ In our study there was a positive family history of cancer colon is in 6\%(3/50) of 
cancer colon patients group and 3.3\% (1/30) of control group and this was agreed with Bresalier in 2010, The risk of colorectal cancer in first degree relatives is increased two to three-fold. ${ }^{28}$ But Haug et al found no relation between positive family history of cancer colon and incidence of cancer colon. ${ }^{25}$

In this study, $32 \%$ of cancer colon patients were smokers compared to $3.3 \%$ only of control healthy persons and this difference was statistically significant, and was in agreement with previous studies that found a significance association between cancer colon and smoking and explained that as smoke contains many carcinogenic materials causes damage to the DNA and with time the body cannot repair this damage. ${ }^{29,30}$ But previous studies did not found any relation between smoking and cancer colon. ${ }^{31,32,33}$

There was a suggestion that there are differences in epidemiology, clinical presentation, histopathology and outcome between patient with cancer in the right and the left side of the colon. ${ }^{34}$ The etiology for this is unclear, but this may be due to the difference embryologic development of the two segments of the colon which may lead to different molecular biological patterns of the tumors which therefore represent a two separate disease entities. ${ }^{35}$ Our results supported this suggestion as we found that the right colon cancer showed statistically significant $(\mathrm{P}$ value $=0.002 *)$ increase in M2-PK level (11.06 \pm 2.69$)$ more than the left side colon cancer $(8.56 \pm 2.38)$.

In this study only 20 patients were operable and surgical treatment was done with basal mean M2-PK was $10.15 \pm 2.03$ but after 6 weeks follow up the results showed significantly $(\mathrm{P}$ value $=0.001)$ marked decrease in mean value of M2PK to $2.35 \pm 0.88$.

The results of this study showed that almost all cancer colon patients had M2-
PK level more or equal to $3.5 \mathrm{U} / \mathrm{ml}$, however $93.3 \%$ of control individual had M2-PK level less than $3.5 \mathrm{U} / \mathrm{ml}$ and this difference is statistically significant ( $p$ value $=0.001^{*}$ ). The cutoff value for fecal tumor M2-PK levels was $4 \mathrm{U} / \mathrm{ml}$, as recommended by the manufacturer and other similar studies. ${ }^{36,37}$ Schulze, 2000 reported a diagnostic specify of $89 \%$ with a higher sensitivity when compared with CEA, CA19-9 and CA72-4. He also concluded that M2-PK should be used in combination with CEA to increase the sensitivity. ${ }^{38}$

Limitations of the study: Although in this study tumor fecal M2-PK can be a useful biomarker in diagnosis of cancer colon with relative sensitivity and specificity, there are still several limitations in this study as a relative small number of participants and a significant heterogeneity among patients and control.

\section{Recommendations:}

Our recommendations are to perform further studies with larger numbers of patients to put M2-PK as one of the screening markers for cancer colon.

\section{Acknowledgment:}

The authors are grateful to Dr. Jehan Hassan Sabry; prof of clinical and chemical pathology at faculty of medicine, Benha University for her assistance in conduction of laboratory investigations for all study participants.

\section{References:}

1. Kuipers EJ, Grady WM, Lieberman D, Seufferlein T, Sung JJ, Boelens PG, van de Velde CJ, Watanabe T. Colorectal cancer. Nat. Rev. Dis. Primers. doi: 10.1038/nrdp.2015.65.

2. Ferlay J, Shin HR, Bray F, Forman D, Mathers C, Parkin DM. Estimates of worldwide burden of cancer in 2008: GLOBOCAN 2008. Int. J. Cancer. 2010; 127(12): 2893-917.

3. Jemal A, Bray F, Center MM, Ferlay

J, Ward E, Forman D. Global cancer 
statistics. CA: CA Cancer J Clin. 2011; 61(2): 69-90.

4. Zalata HR, Tang C, Ming S. Colorectal carcinoma: Pathological study of 83 schistosoma and non schistosoma associated Egyptian patients. Arab Journal Gastroenterology. 2000.

5. Assess Your Risk for Colorectal Cancer and screening. American Society of Colon and Rectal Surgeons 2014. Available from: http: //www.fascrs.org/patients/treatments and screenings 25/4/2017.

6. Kuntz KM, Lansdorp-Vogelaar I, Rutter CM, Knudsen AB, van Ballegooijen M, Savarino JE, Feuer EJ, Zauber AG. A systematic comparison of microsimulation models of colorectal cancer: the role of assumptions about adenoma progression. Med. Decis. Mak. 2011; 31(4):530-9.

7. Lansdorp-Vogelaar I, van Ballegooijen M, Zauber AG, Habbema JD, Kuipers EJ. Effect of rising chemotherapy costs on the cost savings of colorectal cancer screening. J. Natl. Cancer Inst. 2009; 101(20):1412-22.

8. Walsh J, Terdiman J. Colorectal cancer screening - scientific review. JAMA 2003; 289(10):1288-96.

9. Schreuders EH, Ruco A, Rabeneck L, Schoen RE, Sung JJ, Young GP, Kuipers EJ. Colorectal cancer screening: a global overview of existing programmes. Gut. 2015; 64(10):1637-49.

10. Pox CP, Altenhofen L, Brenner $\mathrm{H}$, Theilmeier A, Von Stillfried D Schmiegel W. Efficacy of a nationwide screening colonoscopy program for colorectal cancer. Gastroenterology 2012; 142(7):1460-7.

11. Foo AS, Thia JJ, Ng ZP, Fong NP, Koh GC. Colorectal cancer screening: The effectiveness of education on its barriers and acceptability. Asia Pac J Public Health. 2012; 24(4): 595-609.

12. Hathurusinghe HR, Goonetilleke KS, Siriwardena AK. Curreny status of tumor M2 pyruvate kinase (tumor M2-
PK) as a biomarker of gastrointestinal malignancy. Ann. Surg. Oncol. 2007; 14(10):2714- 20.

13. CDC Data and Statistics Feature. Top 10 Cancers Among Women May 2011. Available from: http://198.246.98.21/Features/dsWomen Top10Cancers/.

14. Gado A, Ebeid B, Abdelmohsen A. Colorectal cancer in Egypt is commoner in young people: Is this cause for alarm? Alexandria Journal of Medicine 2014; 50(3): 197-201.

15. Sakr SA, Abdel-Wahed MM, Abdou AG, El-Adely EK. Histochemical alterations in colorectal carcinoma and adenoma in Egyptian patients. Journal of Coastal Life Medicine 2016; 4(1): 14-20.

16. Khuhaprema $\mathrm{T}$ and Srivatanakul P. Colon and rectum cancer in Thailand: an overview. Japanese journal of clinical oncology 2008; 38(4): 237- 243

17. Abotchie PN, Vernon SW and Du XL. Gender differences in colorectal cancer incidence in the United States, 1975-2006. Journal of Women's Health (Larchmt) 2012; 21(4): 393-400.

18. Murphy G, Devesa SS, Cross AJ, Inskip PD, McGlynn KA, Cook MB. Sex disparities in colorectal cancer incidence by anatomic subsite, race and age. Int $\mathbf{J}$ Cancer 2011; 128(7): 1668-75.

19. Rim SH, Seeff L, Ahmed F, King JB, Coughlin SS. Colorectal cancer incidence in the United States, 19992004. Cancer 2009; 115(9): 1967-1976

20. Hamilton SR, Bosman FT, Boffetta P. Carcinoma of the colon and rectum. In: WHO Classification of Tumours of the Digestive System 2010. Bosman FT, Carneiro F, Hruban RH, Theise ND, eds. Lyon: IARC Press, 13446.

21. Julie k Bassett, Gianluca S, Dallas R, Laura Baglietto, Kavitha Krishnan, John Hopper, and Graham G.Body size, weight change, and risk of colon cancer.Caner epidemiol. Biomarker Prev; 19(11) November 2010. 
22. Kim MC, Kim CS, Chung TH, Park HO, Yoo CI. Metabolic syndrome, lifestyle risk factors, and distal colon adenoma: A retrospective cohort study. World J Gastroenterol 2011; 17(35):4031-7.

23. Ortiz AP, Thompson CL, Chak A, Berger NA, Li L. Insulin resistance, central obesity, and risk of colorectal adenomas. Cancer 2012; 118(7):1774-81. 24. Levi Z, Kark JD, Barchana M, Liphshitz I, Zavdi O, Tzur D, Derazne E, Furman M, Niv Y, Gordon B, Afek A, Shamiss A. Measured body mass index in adolescence and the incidence of colorectal cancer in a cohort of 1.1 million males. Cancer Epidemiol. Biomarkers Prev. 2011; 20(12):2524-31.

25. Haug U, Rothenbacher D, Wente MN, Seiler CM, Stegmaier C, Brenner H. Tumor M2-PK as a stool marker for colorectal cancer: comparative analysis in a large sample of unselected older adults vs colorectal cancer patients. Br J Cancer 2007; 96(9):1329-34.

26. Fung TT, van Dam RM, Hankinson SE, Stampfer M, Willett WC, $\mathrm{Hu}$ FB. Low carbohydrate diets and all cause and cause specific mortality: two cohort studies. Ann Intern. Med. 2010; 153(5): 289-298.

27. World Cancer Research Fund/American Institute for Cancer Research. Food, Nutrition, Physical Activity, and the Prevention of Cancer: a Global Perspective. Washington DC: AICR; 2007. p. 284. Available at url: http://eprints.ucl.ac.uk/4841/1/4841.

28. Bresalier RS. Colorectal cancer. In: Feldman M, Friedman LS, Brandt LJ, eds. Schleisenger's and Fordtran's Gastrointestinal and Liver Disease. 9th ed. Philadelphia: Saunders 2010; 219238.

29. Kaneko R, Sato Y, An Y, Nakagawa M, Kusayanagi S, Kamisago S, Umeda T, Ogawa M, Munakata K, Mizuno K. Clinico- epidemiologic study of the metabolic syndrome and lifestyle factors associated with the risk of colon adenoma and adenocarcinoma. Asian Pac. J. Cancer Prev. 2010; 11(4):975-83

30. Friedenberg FK, Singh $M$, George NS, Sankineni A, Shah S. Prevalence and distribution of adenomas in black Americans undergoing colorectal cancer screening. Dig. Dis. Sci. 2012; 57(2): 489- 95.

31. Sandler RS, Sandler DP, Comstock GW. Helsing KJ, Shore DL. Cigarette smoking and the risk of colorectal cancer in women. J. Natl. Cancer Inst. 1988; 80(16): 1329-1333.

32. David Limsui, Robert A., Loris $\mathrm{S}$ Tillmans, Alice $\mathrm{H}$ Wang, Daniel J Weisenberger, Peter W Larid et al. Cigarette smoking and colorectal cancer risk by molrcular defined subtypes. J. Natl Cancer Inst. 2010 Jul 21; 102 (14): 1012-1022.

33. Nordlund LA, Carstensen JM, and Pershagen G. Cancer incidence in female smokers: a 26-year follow-up. Int. J. Cancer. 1997; 73(5): 625-8

34. Benedix F, Kube R, Meyer F, Schmidt U, Gastinger I, Lippert $\mathrm{H}$. Comparison of 17,641 patients with right- and left-sided colon cancer: differences in epidemiology، perioperative course, histology, and survival. Dis. Colon Rectum 2010; 53(1):57-64.

35. Hutchins G, Southward K, Handley $\mathrm{K}$ et al. Value of mismatch repair, KRAS and BRAF mutations in predicting recurrence and benefits from chemotherapy in colorectal cancer. J. Clin. Oncol. 2011; 29(10):1261-70.

36. 36) Hardt PD, Mazurek S, Toepler M, Toepler M, Schlierbach P, Bretzel RG, Eigenbrodt E, Kloer HU. Fecal tumor M2 pyruvate kinase: A new sensitive screening tool for colorectal cancer. Br. J. Cancer. 2004; 91(5):980 4.

37. Naumann M, Schaum B, Oremek GM, Hanisch E, Rösch W, Mössner J, Caspary WF, Stein J. Faecal pyruvate 
kinase type M2 - a valid screening parameter for colorectal cancer? Preliminary results from a multicenter comparative study. Dtsch. Med. Wochenschr.2004; 129(34-35);1806 -7.
38. Schulze G. The tumor marker tumor M2-PK: An application in the diagnosis of gastrointestinal cancer. Anticancer Res. 2000; 20(6): 4961- 4. 